\title{
Effective Phototransformation in a Heterostructure Based on Copper(I) Oxide and Cadmium Tin Oxide
}

\author{
G. N. Shelovanova and T. N. Patrusheva* \\ Siberian Federal University, Krasnoyarsk, 660041 Russia \\ *e-mail:pat55@mail.ru \\ Received June 29, 2016
}

\begin{abstract}
We present a heterostructure consisting of anodic copper oxide $\mathrm{Cu}_{2} \mathrm{O}$ on a copper substrate and a transparent $\mathrm{Cd}-\mathrm{Sn}-\mathrm{O}$ conducting film for use in solar cells. Focusing on simplicity and the availability of film fabrication techniques, we chose anodic oxidation for forming the $\mathrm{Cu}_{2} \mathrm{O}$ film and the extraction-pyrolysis technique for forming the transparent $\mathrm{Cd}-\mathrm{Sn}-\mathrm{O}$ conducting layer. We demonstrate the possibility of considerable enhancement of the phototransformation efficiency in the $\mathrm{Cu}-\mathrm{Cu}_{2} \mathrm{O} / \mathrm{Cd}-\mathrm{Sn}-\mathrm{O}$ structure over this parameter in the $\mathrm{Cu}-\mathrm{Cu}_{2} \mathrm{O}$ structure.
\end{abstract}

DOI: $10.1134 / \mathrm{S} 1063783417020263$

\section{INTRODUCTION}

The need for solving energy problems associated with the drain on traditional energy resources and environmental degradation of the Earth stimulates the development of devices for direct conversion of solar energy into electricity. Here, one of the key moments is the search for new materials and structures for effective phototransformation. Among the promising materials for such applications is, in particular, copper(I) oxide, whose properties have been studied since the twenties of the last century. That time, cuprousoxide rectifiers were developed and their characteristics were studied.

Interest in $\mathrm{Cu}_{2} \mathrm{O}$ was temporary when new semiconductor compounds appeared; however, later it was renewed due to modern technological capabilities.

The vast majority of solar cells are based on $p-n$ junctions, which cannot be formed without involving energy-consuming high-temperature processes. Fabrication of $\mathrm{Cu}_{2} \mathrm{O}$ does not require such solutions. Typical semiconductor solar cells are sensitive to high temperatures, which reduces the efficiency of using focusing systems, since superheating of a semiconductor lowers the phototransformation efficiency. In contrast to silicon, copper(I) oxide can withstand higher superheating temperatures due to its wider band gap. Copper used as a substrate is characterized, along with the low resistance, by its extremely high thermal conductivity and good heat dissipation. This makes it possible to use the focusing systems without additional coolers, which also reduces the cost of fabrication of a solar cell constructed from these elements.

To design a solar cell, a second electric contact is necessary. The role of this contact is played by a trans- parent $\mathrm{Cd}-\mathrm{Sn}-\mathrm{O}$ conducting film deposited onto the $\mathrm{Cu}_{2} \mathrm{O}$ surface. In the literature [1], it was proposed to increase the conductivity of the films without transparency loss using double and tertiary oxides. Films of the solutions of cadmium and tin extracts are of interest. The electrical properties of tin- or zinc-doped cadmium oxides are better than those of other transparent conducting films.

\section{EXPERIMENTAL}

Among promising techniques for $\mathrm{Cu}_{2} \mathrm{O}$ fabrication are thermal oxidation, electrodeposition, chemical deposition, and anodic oxidation.

In this study, we prepared copper(I) oxide by anodic oxidation of electrical copper grade M0 $(99.95 \% \mathrm{Cu})$ in an electrochemical cell with a platinum cathode. Before anodizing, the foil surface was mechanically cleaned of oxides, degreased in a hot soda liquor, and then electrochemically polished in the sulfamic acid aqueous solution at a current density of $j=100 \mathrm{~mA} / \mathrm{cm}^{2}$ for $3 \mathrm{~min}$ to additionally clean the surface.

Highly transparent conducting films are formed by high-cost magnetron sputtering or electron-beam deposition methods, which require vacuum equipment, high-purity chemical reagents, and a great deal of energy. However, since cadmium compounds are toxic, their fabrication by conventional vacuum sputtering of targets has not been widespread. We obtained complex-oxide films by the extraction-pyrolytic method [2], which is used in this work to form the $\mathrm{Cd}-\mathrm{Sn}-\mathrm{O}$ film. The method includes extraction of target components from aqueous solutions, mixing the 
extracts in a desired ratio, their deposition onto substrates, and pyrolysis. This technique was chosen due to the homogeneity of the intermediate and final products and the possibility of fabricating materials with any ratio of target components. The extraction agent used was a mixture of carboxylic acids, including capronic, caprylic, enanthic, and pelargonic ones. Using extraction, we obtained cadmium and tin carboxylates. To refine metal concentrations in the extracts, we prepared reextracts and studied them by atomic absorption with an AAS-3 device. The working solutions were prepared by mixing the extracts in ratios of $1: 1,2: 1,4: 1,6: 1$, and $8: 1$. The prepared solutions were used to deposit the $\mathrm{Cd}-\mathrm{Sn}-\mathrm{O}$ films of a specified composition by substrate rotation.

Carboxilate solutions have low surface tension and wet well any substrates. To uniformly distribute the solution over the substrate surface, we used centrifuging for $1 \mathrm{~min}$ at a centrifuge speed of 2500-3000 rpm. The layer dried at room temperature was placed in a vertical furnace for pyrolysis at a temperature of $450^{\circ} \mathrm{C}$ for $3 \mathrm{~min}$. After cooling the film, the cycles involving solution deposition, drying, and pyrolysis were repeated for 3-5 times until a film thickness of 50$150 \mathrm{~nm}$ was obtained. The film thickness was estimated by the disjoining pressure of the solution calculated using the surface tension data [3].

The anodic oxidation and extraction-pyrolytic techniques have almost no structure area limitations.

The obtained samples were studied using physicochemical methods. X-ray diffraction analysis of the $\mathrm{Cu}_{2} \mathrm{O}$ film was performed on a DRON-3 derivatograph. The copper(I) oxide film microstructure was investigated on a Hitachi TM-1000 scanning electron microscope (SEM). X-ray diffraction patterns were obtained on an X'Pert PRO with a PIXcel detector (PANalytical) in $\mathrm{Cu} K_{\alpha}$ radiation.

The $\mathrm{Cu}_{2} \mathrm{O}$ conductivity type was determined by the thermopower technique [4]. In this work, the $\mathrm{Cu}_{2} \mathrm{O}$ band gap was determined from the temperature dependence of the semiconductor resistance. The sample was placed into a measuring chamber with an electrical heater. The resistance was detected by a digital device. The temperature was measured by a differential thermocouple at free ends of which the thermopower proportional to the difference between room and measured temperatures is formed. The thermopower was detected by a digital voltmeter. The temperature was determined using a special calibration table based on the thermopower values.

\section{FORMATION OF THE $\mathrm{Cu}_{2} \mathrm{O}$ LAYER ON A COPPER SUBSTRATE AND PROPERTIES OF THE $\mathrm{Cu} / \mathrm{Cu}_{2} \mathrm{O}$ STRUCTURE}

The anodic copper(I) oxide is conventionally prepared using electrolytes based on the sulfuric acid and potassium hydroxide; in this case, along with $\mathrm{Cu}_{2} \mathrm{O}$, the secondary $\mathrm{CuO}$ oxide forms, which is less photoactive being a monovalent copper oxide. As an electrolyte, we used the $5 \%$ aqueous solution of sulfamic (amidosulfonic) acid $\mathrm{NH}_{2} \mathrm{SO}_{3} \mathrm{H}$. At temperatures of $20-30^{\circ} \mathrm{C}$, the maximum sulfamic acid concentration in the aqueous solution is $10 \%$; however, at this concentration, the forming oxide is immediately etched. Gradually lowering the concentration, we obtained the stable $\mathrm{Cu}_{2} \mathrm{O}$ formation in the $5-\% \mathrm{NH}_{2} \mathrm{SO}_{3} \mathrm{H}$ solution.

As the anodic process time increases, the film thickness grows at all the investigated current densities. However, the current density growth leads to an increase in the applied voltage, which results in film etching due to the switching of the polishing mechanism and the film thickness decreases. For instance, at an anodizing current density of $2 \mathrm{~mA} / \mathrm{cm}^{2}$, the maximum film thickness was $6 \pm 0.5 \mu \mathrm{m}$, while at a density of $6 \mathrm{~mA} / \mathrm{cm}^{2}$, it was about $3 \pm 0.5 \mu \mathrm{m}$.

The formation of $\mathrm{Cu}_{2} \mathrm{O}$ in the film was visually observed at exposure to the ammonia solution, in which $\mathrm{Cu}_{2} \mathrm{O}$ is dissolved with the formation of the colorless complex $\left[\mathrm{Cu}\left(\mathrm{NH}_{3}\right)_{2}\right]^{+}$rapidly oxidizing in air to the blue complex $\left[\mathrm{Cu}\left(\mathrm{NH}_{3}\right)_{4}\left(\mathrm{H}_{2} \mathrm{O}\right)_{2}\right]_{2}^{+}$.

Figure 1 shows a $\mathrm{SEM}$ image of the anodic $\mathrm{Cu}_{2} \mathrm{O}$ film. One can see a branched structure, which allows the area of photon effect to be increased and, thus, enhances the phototransformation efficiency.

The X-ray diffraction pattern in Fig. 2 shows no secondary products of the electrochemical reaction in the film, which speaks about the correct choice of the electrolyte and $\mathrm{Cu}_{2} \mathrm{O}$ formation regimes.

All the films were found to have the $p$-type conductivity, which is consistent with the literature data for this material prepared by anodic oxidation [5]. As is known, the band gap of the anodic copper oxide is $1.8-2.2 \mathrm{eV}$, depending on fabrication technique used.

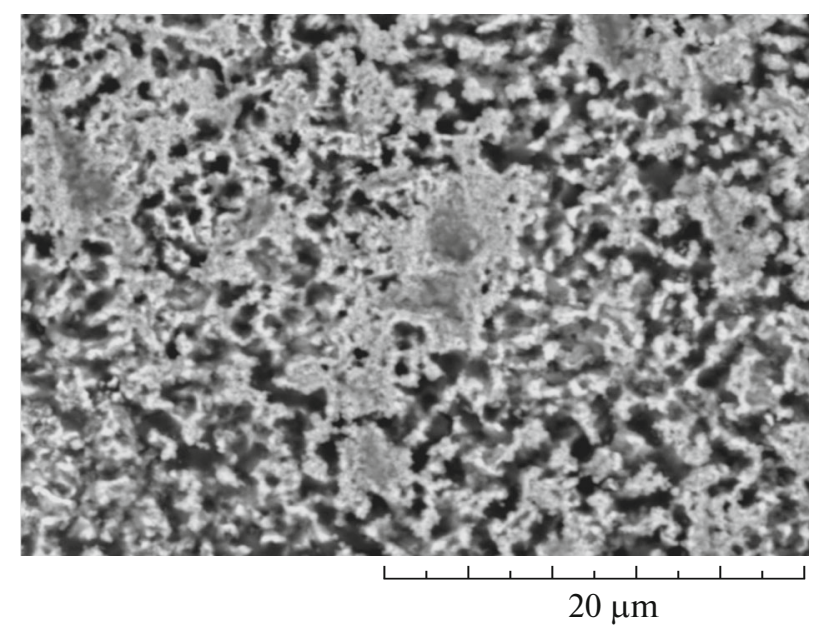

Fig. 1. Microphotograph of the $\mathrm{Cu}_{2} \mathrm{O}$ film. 


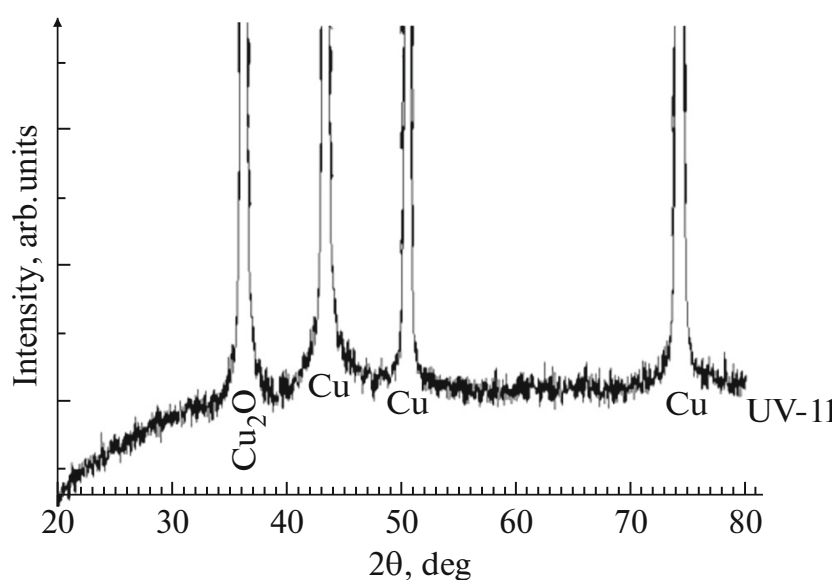

Fig. 2. X-ray diffraction pattern of the $\mathrm{Cu}_{2} \mathrm{O}$ film on a copper substrate.

For instance, according to the literature data, the copper(I) oxide prepared by thermal oxidation has a band gap of $1.9 \mathrm{eV}$; the band gap value reported for the compound prepared by low-temperature chemical deposition is $2.36 \mathrm{eV}$; and at the anodic oxidation of cooper in the sulfuric acid solution the band gap is $2.2 \mathrm{eV}[6-9]$.

As any semiconductor, the resistance of copper(I) oxide exponentially decreased with increasing temperature due to thermal carrier generation (Fig. 3).

The band gap was calculated from the temperature dependence of the resistance using the formula

$$
E_{g}=2 k \tan \alpha=2 k \frac{\ln R_{1}-\ln R_{2}}{\frac{1}{T_{1}}-\frac{1}{T_{2}}},
$$

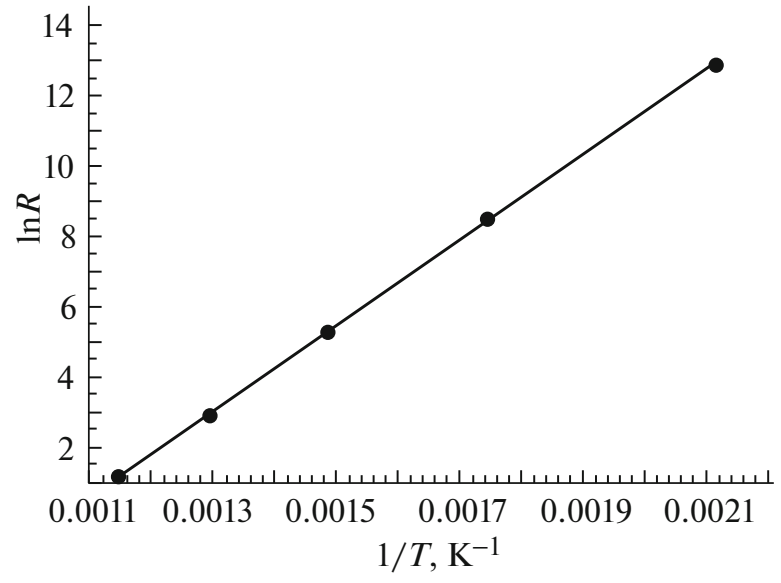

Fig. 3. Dependence of the logarithm of the $\mathrm{Cu}_{2} \mathrm{O}$ film resistance on reciprocal temperature.

where $E_{g}$ is the band gap, $k$ is the Boltzmann constant, $R_{1}$ and $R_{2}$ are the resistances of the neighboring points, and $T_{1}$ and $T_{2}$ are the temperatures of these points.

The band gap was found to be $2.13 \mathrm{eV}$.

This result was additionally confirmed by a spectrogram obtained on a Specord M400 spectrometer (Fig. 4). In this spectrogram, the optical density changes along a wavelength of $580 \mathrm{~nm}$, which corresponds to a band gap of $E_{g}=2.11 \mathrm{eV}$ according to the formula

$$
\lambda=h c / E_{g},
$$

where $\lambda$ is the wavelength $(\mu \mathrm{m}), h$ is the Planck's constant, $c$ is the speed of light, and $E_{g}$ is the semiconductor band gap $(\mathrm{eV})$.

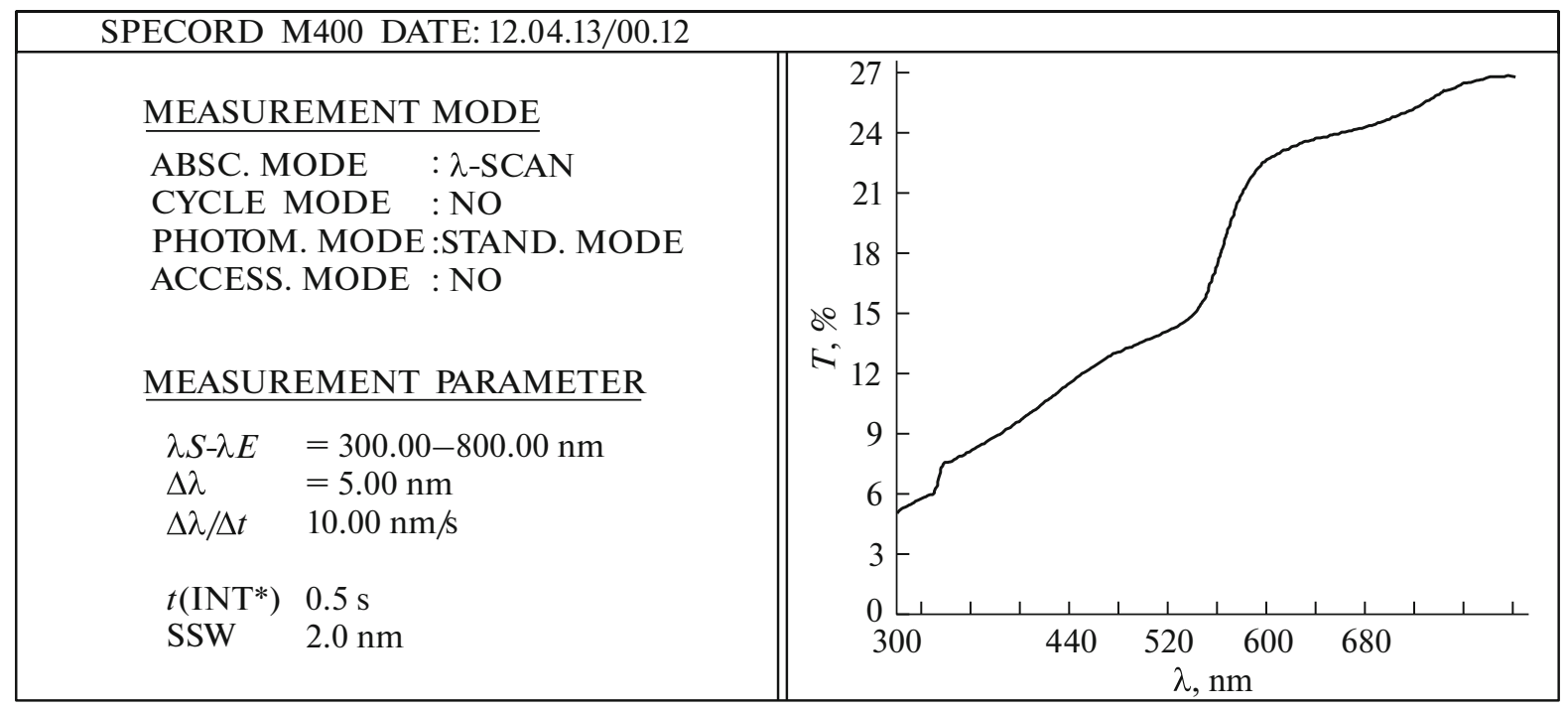

Fig. 4. Reflection spectrum of anodic $\mathrm{Cu}_{2} \mathrm{O}$. 


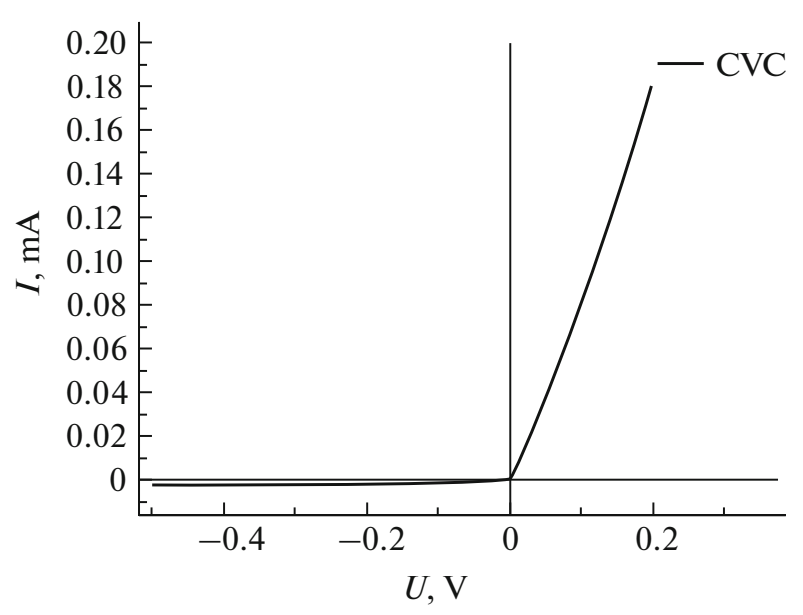

Fig. 5. $I-V$ characteristic of the $\mathrm{Cu} / \mathrm{Cu}_{2} \mathrm{O}$ structure.

The $I-V$ characteristic of the $\mathrm{Cu}-\mathrm{Cu}_{2} \mathrm{O}$ structure (Fig. 5) obtained by a four-probe technique [10] shows the presence of a Schottky barrier as a basis for the development of a photoconverter.

\section{PHOTOELECTRIC PROPERTIES OF THE $\mathrm{Cu}-\mathrm{Cu}_{2} \mathrm{O} / \mathrm{Cd}-\mathrm{Sn}-\mathrm{O}$ STRUCTURE}

After 3-5 cycles of solution deposition and pyrolysis at $450^{\circ} \mathrm{C}$, we obtained transparent films with the surface resistance decreasing with increasing film thickness. The growth of cadmium mole content leads to a decrease in the surface resistance of the $\mathrm{Cd}-\mathrm{Sn}-$ $\mathrm{O}$ films; at a ratio of $\mathrm{Cd}-\mathrm{Sn}=4: 1$, the resistance was $400 \Omega / \square$ and at $\mathrm{Cd}-\mathrm{Sn}=6: 1,200 \Omega / \square$. With a further increase in the mole fraction of cadmium, the surface resistance sharply increased (Fig. 6).

The data on photoresponse of the $\mathrm{Cu}-\mathrm{Cu}_{2} \mathrm{O}$ and $\mathrm{Cu}-\mathrm{Cu}_{2} \mathrm{O} / \mathrm{Cd}-\mathrm{Sn}-\mathrm{O}$ structures were obtained using the direct solar light, whose radiation intensity in sunny weather at the Krasnoyarsk latitude is known $\left(825 \mathrm{~W} / \mathrm{m}^{2}\right)$. As a photoresponse parameter, the light short-circuit current was measured. The efficiency of phototransformation of the $\mathrm{Cu}-\mathrm{Cu}_{2} \mathrm{O}$ structure was 2.3\%. After deposition of the transparent $\mathrm{Cd}-\mathrm{Sn}-\mathrm{O}$ contact layer onto the $\mathrm{Cu}-\mathrm{Cu}_{2} \mathrm{O}$ structure, the phototransformation efficiency of the entire structure attained $5.3 \%$. The maximum light short-circuit current density was $9 \mathrm{~mA} / \mathrm{cm}^{2}$, the working light shortcircuit current density was $7 \mathrm{~mA} / \mathrm{cm}^{2}$, the dark shortcircuit current density was $0.4 \mathrm{~mA} / \mathrm{cm}^{2}$, and the light and dark voltages were 0.5 and $0.09 \mathrm{~V}$, respectively.

A significant increase in the phototransformation efficiency as compared with its value of $2.3 \%$ in the $\mathrm{Cu}-\mathrm{Cu}_{2} \mathrm{O}$ structure can be explained by the following factors. We assume that during deposition of the $\mathrm{Cd}-$ $\mathrm{Sn}-\mathrm{O}$ layer, a heterostructure was formed whose energy diagram is shown in Fig. 7.

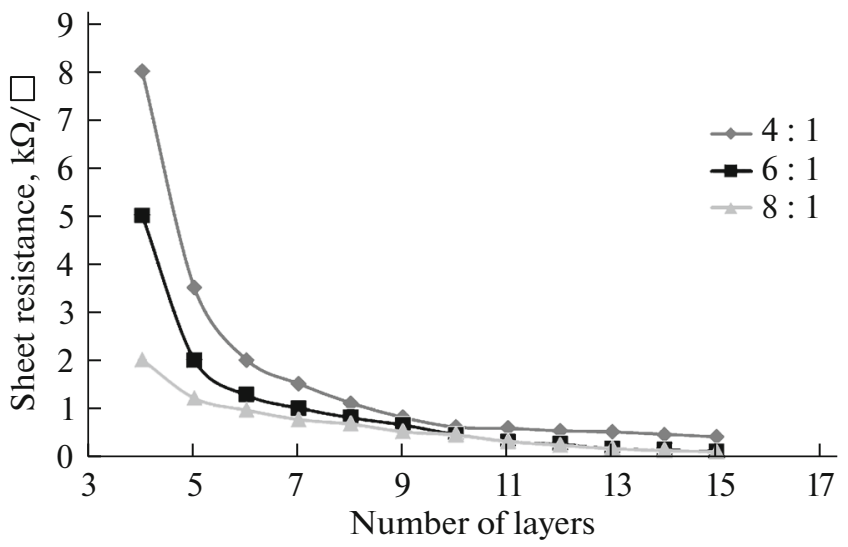

Fig. 6. Dependence of the surface resistance of the film on number $N$ of deposited layers and $\mathrm{Cd}: \mathrm{Sn}$ component ratio.

Since a solar cell operates without external bias, the Fermi level is only for the entire structure. Copper oxide $\mathrm{Cu}_{2} \mathrm{O}$ with a band gap of $2.12 \mathrm{eV}$ is a $p$-type semiconductor and the transparent conducting oxide $\mathrm{Cd}-$ $\mathrm{Sn}-\mathrm{O}$ with a band gap of $\sim 3 \mathrm{eV}$ is an $n$-type semiconductor. A heterojunction with the wide-gap window effect forms. The light with energy lower than the band gap of oxide $\mathrm{Cd}-\mathrm{Sn}-\mathrm{O}$ is transmitted to narrow-gap oxide $\mathrm{Cu}_{2} \mathrm{O}$ almost without absorption. A part of this radiation with energy higher than the band gap of $\mathrm{Cu}_{2} \mathrm{O}$ generates electron-hole pairs, which are separated by the heterojunction field. Since the $\mathrm{Cd}-\mathrm{Sn}-\mathrm{O}$ layer is photoactive in itself, carriers are generated in it as well. High potential barriers at the heterojunction and Schottky barrier do not allow electrons from the $\mathrm{Cd}-\mathrm{Sn}-\mathrm{O}$ layer and holes from the $\mathrm{Cu}_{2} \mathrm{O}$ layer to flow to the neighboring areas. As a result, the $\mathrm{Cu}_{2} \mathrm{O}$ layer is charged positively and the $\mathrm{Cd}-\mathrm{Sn}-\mathrm{O}$ layer, negatively. Thus, the heterostructure works as a solar cell, which does not require diffusion processes, melting, or epitaxy to be fabricated, and the copper and conducting $\mathrm{Cd}-\mathrm{Sn}-\mathrm{O}$ layer work as ohmic contacts.

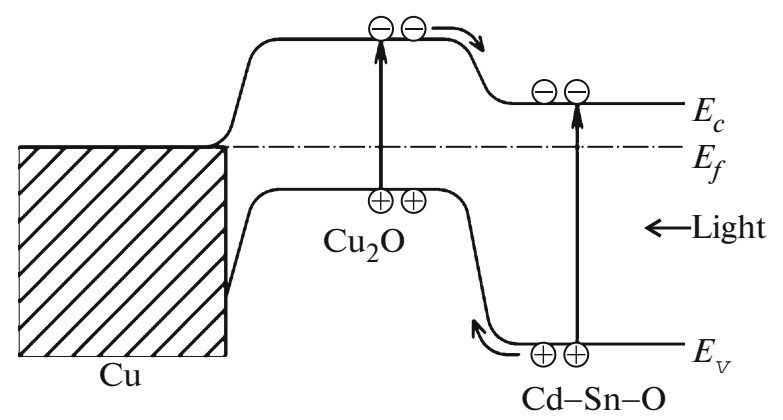

Fig. 7. Energy band diagram of the $\mathrm{Cu}-\mathrm{Cu}_{2} \mathrm{O} / \mathrm{Cd}-\mathrm{Sn}-\mathrm{O}$ heterostructure. 


\section{CONCLUSIONS}

The main competitors of solar cells based on copper(I) oxide in the market are commercial solar cells based on single-crystal, polycrystalline, hydrogenized, and amorphous silicon. However, we should list the significant advantages of the $\mathrm{Cu}_{2} \mathrm{O}$-based solar cells. These are the use of wide-spread materials without the need for high purity, fabrication simplicity, the use of standard inexpensive equipment, wide operation temperature range of the obtained solar cells, low toxicity of production and components, mechanical strength, and corrosion resistance of initial copper.

The possibility of adapting the fabrication process to CAD systems provides the potential for the development of solar cells with large working surfaces of different curvatures, which significantly broadens their application range over solar cells of other types and makes them very attractive for wide commercial use.

Having analyzed the literature and experimental data, we can state that the $\mathrm{Cu}-\mathrm{Cu}_{2} \mathrm{O} / \mathrm{Cd}-\mathrm{Sn}-\mathrm{O}$ heterostructure formed by low-cost methods from inexpensive materials can become a basis for solar cells used for small-scale power generation.

\section{ACKNOWLEDGMENTS}

We are grateful to A.Ya. Korets for optical measurements and G.A. Bondarenko for X-ray investigations.

This study was supported by the Krasnoyarsk Science Foundation and Russian Foundation for Basic Research, project no. 15-48-04224.

\section{REFERENCES}

1. L. Castañeda, D. S. Ginley, and C. Bright, Mater. Sci. Appl. 2, 1233 (2011).

2. A. I. Khol'kin and T. N. Patrusheva, Extraction-Pyrolytic Method of Obtaining of Oxide Functional Materials (KomKniga, Moscow, 2006) [in Russian].

3. T. N. Adrianova, A. A. Zakharov, E. A. Mironov, and S. N. Slyun'kov, in Proceedings of the Conference "Ultradispersed Powders and Materials," Krasnoyarsk State Technical University, Krasnoyarsk, October 5-7, 1999), p. 134.

4. L. P. Pavlov, Methods for Measuring the Parameters of Semiconductor Materials (Vysshaya Shkola, Moscow, 1990) [in Russian].

5. L. A. Svetlichnaya, in Elektrokhimiya (Taganrog Technological Institute, Southern Federal University, Taganrog, 2009), Vol. 45, Issue 7, p. 858 [in Russian].

6. A. H. Jayatissa, K. Guo, and A. C. Jayasuriya, Appl. Surf. Sci. 23 (255), 9474 (2009).

7. T. D. Golden, M. G. Shumsky, and Y. Zhou, Chem. Mater. 8 (10), 2499 (1996).

8. M. T. Nair and L. Guerrero, Appl. Surf. Sci. 150 (1-4), 143 (1999).

9. E. Fortin and D. Masson, Solid-State Electron. 25 (4), 281 (1982); G. T. D. Olden, M. G. Shumsky, and Y. Zhou, Chem. Mater. 8 (10), 2499 (1996).

10. V. D’yakonov, Kompon. Tekhnol. 10, 137 (2010).

Translated by E. Bondareva 